\title{
Mauro Bonazzi, À la recherche des idées : platonisme et philosophie hellénistique d'Antiochus à Plotin
}

\section{George Karamanolis}

\section{OpenEdition}

\section{Journals}

\section{Electronic version}

URL: https://journals.openedition.org/philosant/707

DOI: 10.4000/philosant.707

ISSN: 2648-2789

Publisher

Éditions Vrin

\section{Printed version}

Date of publication: 1 November 2016

Number of pages: $228-230$

ISBN: 978-2-7574-1472-9

ISSN: 1634-4561

\section{Electronic reference}

George Karamanolis, "Mauro Bonazzi, À la recherche des idées : platonisme et philosophie hellénistique d'Antiochus à Plotin", Philosophie antique [Online], 16 | 2016, Online since 01 November 2018,

connection on 07 December 2022. URL: http://journals.openedition.org/philosant/707 ; DOI: https:// doi.org/10.4000/philosant.707

\section{(c)}

Creative Commons - Attribution-NonCommercial-NoDerivatives 4.0 International - CC BY-NC-ND 4.0 https://creativecommons.org/licenses/by-nc-nd/4.0/ 
this second stage the prominent philosophers of the time (exemplified in this volume by Alexander of Aphrodisias, later Stoics such as Seneca, and later Platonist thinkers, including Plotinus) became aware that they needed to position their own views in relation to Aristotle's account of causation.

Aristotle's account, with its ambition to be an exhaustive causal analysis of reality, motivated the philosophers of the Imperial period to produce either alternative but equally comprehensive systems, or complementary ones to it. Thinkers of this time thus engage in re-interpreting, each in their own terms, alternative systems of causes that their contemporaries or even predecessors had developed. Their overall goal is to look for a theoretical reconciliation, as it were, and a single comprehensive theory that could incorporate systems of causes that were originally different and remained difficult to fit together. But the exercise was fruitful, in that it gave raise to much philosophical thinking that is still for us to fully explore. And this is one of the points that I take the editors want to make : looking at this period in the history of philosophy is exciting and this stimulating book is intended to open up many further avenues for research that will take forward the work done so far.

Anna Marmodoro Corpus Christi College, Oxford

Mauro BonazzI, À la recherche des idées : platonisme et philosophie hellénistique d'Antiochus à Plotin, Vrin, Paris, 2015, 176 p. (Histoire des doctrines de l'Antiquité classique, 46) ISBN : 978-2-7116-2578-9.

Mauro Bonazzi is well known among scholars of ancient philosophy for his many valuable contributions in the area of late ancient philosophy. His papers on Antiochus, Eudorus, Plutarch, and the Anonymous commentator of the Theaetetus are interesting, learned and thought provoking. In his new book he sets out to offer a synthetic overview of the history of Platonism from Antiochus to Plotinus. This is an extremely rich period of the history of Platonism. To begin with, we encounter as diverse philosophical profiles of Platonists as those of Antiochus, Plutarch, Numenius, the Anonymous in Theaetetum, and Plotinus. Antiochus rejects the sceptical academic tradition and sets out to revive the ancient Academy, Plutarch and the Anonymous in Theaetetum try to combine both strands of earlier Platonism, Numenius is inspired by the Pythagorean tradition, while Plotinus accommodates all these aspects in his work. As a result, Platonists take different stances on theory of knowledge, metaphysics, and ethics. It is not, however, only the case that Platonists disagree with each other as to how to interpret Plato's philosophy as a whole and how to reconstruct specific areas of Plato's philosophy, such as epistemology and ethics. Contemporary Peripatetics also disagreed about the interpretation of Aristotle. The disagreement of Platonists though is the result of the different emphasis they put on parts of Plato's work and also the result of the impact of hellenistic philosophy, especially of Stoicism and scepticism, on their thought. As the title of the book shows, Bonazzi is interested in approaching late Platonist philosophy from this specific point of view.

This approach is well justified. For Antiochus' thought is greatly shaped by Stoicism while he tries to distance himself from academic scepticism, Plutarch sets himself in dialogue with both Stoics and Epicureans while he is inspired by academic scepticism, Numenius and Atticus plead for a purified Platonism but their thought is also influenced by hellenistic philosophies, especially Stoicism, and, finally, Plotinus is in constant dialogue with Stoic philosophy and wary of scepticism.

Bonazzi's book is divided in three main chapters. The first centers on Antiochus ("Les 
Débuts: Antiochus d'Ascalon et l'appropriation du Stoïcisme", p. 15-68). The second chapter focuses mainly on Plutarch but it also considers the Anonymous commentator of the Theaetetus and Alcinous ("Plutarque, Alcinoos et le problème de la transcendance", p. 69-107). Finally, the third chapter is dedicated mainly to Plotinus ("Un regard rétrospectif: Plotin, les platoniciens et le scepticisme", p. 117-151). The book is rounded by an extensive bibliography and an index locorum.

The chapter on Antiochus focuses particularly on his epistemology, which, as is well known, is considerably influenced by Stoicism, namely the Stoic doctrine of concepts and cognitive impressions. There is some strong evidence to that effect in Cicero's Academica I (Varro, esp. 30-32). Cicero actually accuses Antiochus of becoming Stoic (germanissimus Stoicus, Acad. II.132), and in a sense he is right, since Antiochus adopts a part of the Stoic theory that does not exist in Plato (Acad. II.112-113), the theory of cognitive impressions. The question, however, is how Antiochus justified his epistemological position. The evidence from Cicero suggests that Antiochus argued that one of the criteria for knowledge according to the Stoics, the concepts or ennoiai, capture the Platonic Forms as they appear in the Meno, for instance, where the Forms have a clear epistemological role. Antiochus presumably defended a version of innatism, according to which humans have innate concepts or ideas, as suggested in the Meno, by means of which we perceive something as $\mathrm{X}$ (e.g. horse or table). Bonazzi elaborates well on that point. He discusses in some detail the relevant evidence from Cicero to the effect that Antiochus identified the Stoic concepts with Plato's Forms (p. 32-42). Bonazzi concludes that this cannot be seen as a genuine position of Plato; Antiochus, he claims, rather appropriates the Stoic theory and systematizes Plato's epistemology in a certain way, a strategy that has as a consequence a certain split between Plato and Platonism (p. 50). This is certainly a reasonable, fair judgment. Ancient Platonists, however, are not like modern scholars of Plato, who set out to study Plato's thought and often conclude that certain arguments in Plato do not work. Ancient Platonists set out to interpret Plato in such a way that his philosophy emerges as the best conceivable option on a given question. This is the task that all Platonists in antiquity undertake. How representative of Plato is, for instance, Xenocrates' view that the soul is a self moving number or that the cosmogony of the Timaeus should be understood in a metaphorical sense? Antiochus' strategy is different from the traditional Platonist attitude only to the extent that his materials for the reconstruction of Plato come at least partly from Stoicism. This is indeed new, but the method of proposing a personal reconstruction of Plato is not.

Chapter two takes us to Plutarch, the Anonymous in Theaetetum and Alcinous. Bonazzi examines first Plutarch's position towards the sceptical Academy and pyrrhonism. And he draws our attention to some texts of Plutarch that connect Epicurus and Pyrrho (e.g. Quaest. Conv. 651e-652a). Plutarch apparently maintained that materialism leads to scepticism. But the question is how. Plutarch seems to have suggested that if sense perception is the result of a contact with an object understood as consisting of a cluster of material qualities, then all sense perception is necessarily fallible, because different qualities of the object may affect different people differently. Bonazzi shows well that for Plutarch the scepticism of the Academy is a position considerably different from Pyrrho's radical scepticism, since the latter is a consequence of an empiricist epistemology while the former is the result of a, so to speak, metaphysical epistemology; for sceptical Academics, according to Plutarch, mistrust sensations and the sensible world as a whole, while they trust only the intelligible world and its impact on us. I find Plutarch's argument interesting but not convincing; both Academics and Pyrrhonists doubt the ability of our senses to convey the external reality faithfully to us. If Academics are 
dualists, as Plutarch implies, they need to explain why we fail to know the intelligible reality, the Forms, that account for the identity of sensible things, especially since, as the Theaetetus suggests $(185 \mathrm{~cd})$, it is the soul that perceives through the senses. Plutarch himself maintains a form of scepticism that Bonazzi terms "metaphysical scepticism". According to this version of scepticism, it is the overall human cognitive ability that is doubted given our, human, limitations (p. 101). This sense of scepticism may be found also in Alcinous, claims Bonazzi, for our ability to know is said again to be constrained by our confinement in body (Didaskalikos 155.20-36; p. 109). The reference to notions, ennoiai, that we find in both Plutarch and Alcinous, is not sufficient for winning against the challenge of scepticism. It is Plotinus who will fight scepticism by defending the possibility of man to liberate his intellect from bodily constraints. The last chapter of the book that is devoted to Plotinus focuses on this line of thought.

Bonazzi examines some important passages of Plotinus (esp. from Ennead V.5) that show clearly that for Plotinus the perception of a sensible object is an image (eidolon) and as such is fallible. The fallibility of sense perception is a consequence of the metaphysical status of the perceived object. This, however, does not mean that we are not in a position to acquire true knowledge. This can be attained by the intellect, or the non descended soul, which is capable of recognizing the intellectual reality, that is, what truly is. Bonazzi is right to claim that Plotinus is not confronting scepticism directly (p. 144) and he is also right to stress the similiarities between Plotinus view about the identity of the intellect and the intelligibles and the Peripatetic theory of intellect as we find it in Alexander of Aphrodisias (p. 146-148). But this does not justify the claim, at least not fully, that Plotinus seeks to redefine Platonism through a critical dialogue with Aristotle (p. 148). For as Bonazzi himself acknowledges (p. 148, n. 4), this dialogue with Aristotle permeates Platonism since Antiochus, if not earlier.

Bonazzi shows well, however, that late ancient Platonists are continuously engaged with scepticism; they try different tools in dealing with the sceptical challenge, such as the elements of Stoic epistemology, Plato's Forms, or the Peripatetic theory of intellect. Bonazzi's book is a very welcome addition to the literature about late ancient Platonists and indeed one that stresses the important role of the Platonist epistemological concerns in how their overall interpretation of Plato was shaped. It deserves to be studied by all scholars of late ancient philosophy.

George Karamanolis University of Vienna

Carlos Lévy et Lucia Saudelli (éd.), Présocratiques latins : Héraclite, traductions, introductions et commentaires, Paris, Les Belles Lettres, 2014 (coll. Fragments, 17), LXXII-200 p., ISBN : 978-2-251-74215-1.

Ce livre, issu du programme « Présocratiques Grecs/Présocratiques Latins » financé par l'Agence Nationale de la Recherche (ANR) et dirigé par André Laks et Carlos Lévy, est le fruit d'une tentative fort intéressante de mettre l'accent sur la question de la spécificité de la transmission et de l'utilisation latine des présocratiques. Car sans nul doute, dans le domaine des études présocratiques, les témoignages issus de la tradition latine ne se trouvent pas au même niveau que ceux provenant de la tradition grecque, le préjugé commun étant que la tradition latine ne représente qu'une information grecque traduite, plus ou moins maladroitement, en latin. lxxii

Les auteurs ont entièrement raison de souligner que cette approche se révèle trop réductrice, et tentent de réparer cette injustice en commençant par Héraclite ; ils nous 